\section{New Role for the AEA}

The United Kingdom Atomic Energy Authority at last shows signs of shedding some of its load. Indeed, the publication last week of its fourteenth annual report (HMSO, 13s) may mark a turning point for the organization which has for so long been the major prop of British nuclear power. Although there will inevitably be regret in the authority at the way things seem to be heading, what matters most is that its experience and talent be put to best use in the new industrial framework which is emerging. Happily, the authority seems to be cooperating fully and enthusias. tically in putting together the new structure.

So far, only one of the two new nuclear companies has been announced. It is made up of English Electric (now part of GEC), Babcock and Wilcox, Taylor Woodrow, the IRC and the Atomic Energy Authority. Already the company has reaped a reward for being first off the mark. For one thing, the AEA has handed over to Babcock English Electric the construction of the $250 \mathrm{MW}$ prototype fast reactor at Dounreay. This means that by 1971, when the PFR is complete, the new company will be the only one in the world to have built a fast reactor. The other new company will, of course, be licensed to build the fast reactor, but without the industrial experience it is likely to find itself at a disadvantage. Babcock English Electric has also been able to snap up three officials from the AEA for its board of directorsMr J. C. C. Stewart, member for reactors, Mr N. L. Franklin and Mr H. V. Disney. This is at least one more than the AEA could have expected from its share of the equity, and one explanation is that $\mathrm{Mr}$ Stewart and $\mathrm{Mr}$ Disney will both leave the AEA soon and join the company full time. It has also been announced that the new company has won the contract to build the nuclear power station at Hartlepools for the Central Electricity Generating Board, so it is off to a very good start.

Within the next week or so, it is expected that the details of the organization of the second company will be announced. Again the AEA can be expccted to hold a shareholding, though, as in the first company, it will be doing so only as an interim measure until the nuclear fuol company is formed. Unfortunately, it seems likely that it will take several years to set up the fuel company; legislation will not be introduced before the 1969-70 session of Parliament, which implies that the fuel company will not be set up until late in 1970 .

By then, it is likely that the AEA will have contracted still further. The authority confirmed this week that it is investigating the possibility of closing the Wantage laboratory and transferring its work to Harwell, although it is stressed that so far no firm decision has been made. Wrntage is where the AEA has concentrated most of its commercial work on isotopes, and the laboratory in fact houses the Isotope Research Division of AERE Harwell. By moving the staff at Wantage (which numbers 180) to Harwell, some economies could certainly be made, and the move would also have the benefit of concentrating the authority's work for the support of industry in one laboratory. One of the major projects at Wantage has been the Package Irradiation Plant, used for the sterilization of food and medical instruments.

The authority has used the annual report to answer the critics who claim that the development of the advanced gas cooled reactor has been too expensive. An economic benefit analysis carried out by the authority shows that the $£ 110$ million spent on the

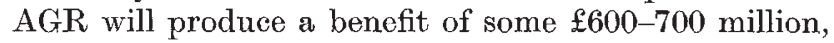
if very conservative ground rules are accepted. The analysis assumes an 80 per cent load factor, 25 year life, and fossil fuel costs well below current levels. Even if the cost of fossil fuels falls as low as $3 d$ a therm, the benefit of the AGR programme would be $£ 350-400$ million. For the further development of reactor systems, the analysis concludes that a benefit of some $£ 800$ million is to be expected.

\section{EDUCATION \\ Buttle of the Bulge}

DURING the five years that have elapsed since the Robbins report was hailed as the first overall plan for higher education in this country, it has become common knowledge that the committee underestimated the likely future output of "qualified school leavers". Thus it was forecast that the proportion of seventeen year olds with two A-levels would rise from 6.9 per cent in 1961 to 8.4 per cent in 1966, whereas it actually rose to $9 \cdot 6$ per cent. In other words, by 1966 the number of leavers with these qualifications was already 16.5 per cent higher than the forecast, and by 1971-72 this discrepancy can be expected to have increased

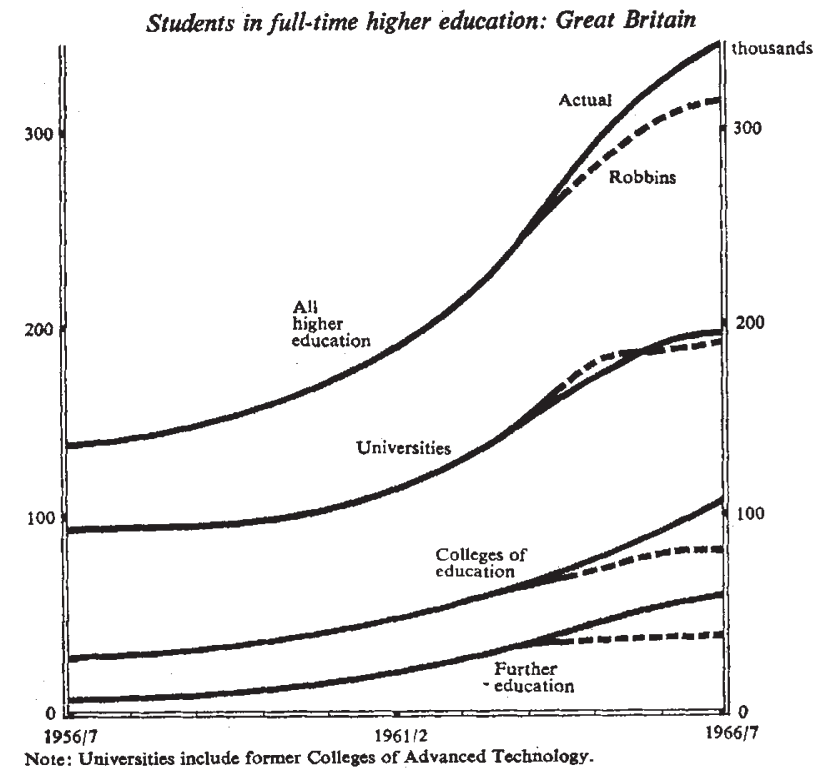

Number of students in full-time higher education in Great Britain. (Reproduced from "The Impact of Kobbins" in Higher Education Review, Cornmarket Press Ltd). 
to 21 per cent. These figures are quoted in a survey appearing in a new periodical, Higher Education Review, and were compiled by Richard Layard, an economics lecturer at the London School of Economics, and John King of the City University (Higher Education Review, edit. by Tyrrell Burgess, Cornmarket Press, 10s).

Although the A-level forecast went wrong, nevertheless the Robbins estimates of the trend to stay at school have been fairly accurate. University development too has followed fairly closely the lines proposed by Robbins, the authors say, but the relationship between universities and the rest of higher education has developed quite differently. In 1962-63, universities provided 60 per cent of places in higher education, and Robbins recommended the same proportion for 1966-67. The actual proportion was, however, 54 per cent, and when the number of well qualified school leavers exceeded the Robbins prediction, the increased supply of students was channelled into non-university sectors. At the present time, an estimated 53 per cent of suitable candidates are accepted by universities compared with an earlier figure of 60 per cent at the time of the Robbins report. Subject balance in the intake has also been upset; in the late fifties and early sixties it was the policy of the University Grants Committee-reiterated by Robbins-that two thirds of additional places in universities should be in science and technology. But as the entry rates in arts and sciences have moved together, from 1961-62 to 1966-67 the proportion of extra places provided for science and technology has been only 37 per cent (43 per cent including colleges of advanced technology). On the arts side, the proportion of all places has increased from 40 per cent to 44 per cent instead of decreasing to 37 per cent. This, the authors say, is "undoubtedly a failure of planning, since it implies that the capital investment in sciences has been higher relative to arts than it would have been if the ensuing teaching commitments had been foreseen". The result has been that the prospective growth of former colleges of advanced technology has been sharply restricted. Had they not become universities they would now be an important focus of expansion.

\section{UNIVERSITIES}

\section{No Volunteers}

THE British Government is obviously having an extremely difficult time trying to find a suitably compliant vice-chancellor or public figure to fill Sir John Wolfenden's chair at the University Grants Committee. At the end of May the trustees of the British Museum announced that Sir John had accepted their offer of the top job in the British museum service, the directorship of the British Museum. The trustees no doubt realized their choice would create problems with the Museums Association, which immediately took umbrage at the appointment of an outsider, even if only as a stopgap measure for the next five years. But the trustees' problems are nothing by comparison with those the Secretary of State for Education must still be facing in his search for a new chairman for the UGC.

Sir John was to have moved to the museum this month, but he has apparently agreed to stay on at the UGC until his successor is found, which means he is likely to be there until some time next year. In the meantime at the museum Mr B. Gray, keeper of the Department of Oriental Antiquities, and a member of the museum staff for about forty years, has taken over as temporary director.

Relations between the Government and the vicechancellors must be close to breaking point, especially after the Government's letter of August 1, which, delivered when most of the vice-chancellors were away in Australia, instructed them not to authorize any new building projects this year. The effects of this moratorium are now beginning to be felt in several universities and they are not increasing the popularity of the Government or of the UGC, which failed to make even a murmur of protest in August. Presumably the Government knew of the negotiations between the trustees of the museum and Sir John long before the May announcement. Its failure to announce Sir John's successor can only mean it has so far failed to persuade a vice-chancellor or an outsider to take on his invidious job.

\section{EMPLOYMENT}

\section{Where the Graduates Went}

The University Grants Committee's sixth annual returns covering the first employment of university graduates who graduated with first or higher degrees in 1966-67 were published on October 22 (HMSO, 7s). British universities produced 36,528 graduates in the year, 26,411 men and 10,117 women, which is an overall increase of 13.6 per cent over 1965-66. The returns reveal all the now familiar trends, the dislike of industrial careers, the trend to social sciences and the trend away from school teaching.

The Government and industry continue to fail to persuade graduates of the advantages of an industrial career. The proportion of all graduates entering commerce and industry fell from 62.7 per cent in $1965-66$ to $62 \cdot 2$ per cent in $1966-67$. These overall figures conceal significant divergent trends between men and women graduates; the proportion of women entering industry rose by 5 per cent to $32 \cdot 3$ per cent while the proportion of men entering the field fell by $2 \cdot 1$ per cent to $70 \cdot 2$ per cent. This year's returns are also gloomy reading for education authorities short of teachers; in 1966- 67 only 13.9 per cent of all graduates entered the profession compared with 15.5 and 17.2 per cent respectively in the two preceding years. The expansion of the civil service, on the other hand, was duly reflected in an increase in recruitment of graduates, from 14.8 to 15.6 per cent of the total. The proportion of graduates in further study was virtually the same as in $1965-66,41.6$ per cent, but this figure conceals a drop in the numbers going on to teacher training and other training and an increase in the proportion starting research or other academic work.

The number of higher degree graduates increased by 27 per cent, and all the statistics in the returns confirm the trends in university education and the attitudes of the graduates which emerged in the Swann and Dainton reports. The only trend which is in line with any of the recommendations in the Swann report is the decreasing proportion of doctorates amongst the higher degree graduates. In 1966-67 the proportion fell yet again to 47.4 per cent; in $1965-66$ it was 55.5 per cent and in 1963-64 as high 